\title{
IMPLEMENTASI KAJIAN BIBLIKAL UNGKAPAN BERBAHAGIALAH ORANG YANG BERTAHAN DALAM PENCOBAAN BERDASARKAN YAKOBUS 1:12-15
}

\author{
Manase Gulo \\ manasegulo@sttab.ac.id
}

\begin{abstract}
This letter of James is shown to the twelve tribes in the overseas, those who are being tossed around related to the socioeconomic level faced by the church, namely the problem between the rich and the poor. So this letter was written before the year 62 AD. In this article we write about the implementation of the blessed expression of those who endure trials in James 1: 12-15. The background is where James says that those who are happy are those who endure trials. In this context it talks about how people's attitudes in the face of temptation, in this case James appealed to the twelve tribes that are overseas so that they endure trials, love God more, persevere in their faith, and are always faithful to God when facing trials. Real happiness is that people are blessed by God, but the problem is only limited to understanding but when confronted with a problem, trials, and lack of needs to be unhappy, less grateful for what is experienced. Therefore this article reminds believers of the true principle of happiness.
\end{abstract}

Keywords: $\quad$ Implementation, Biblical Studies, Blessed, Enduring, Trials.

Abstraksi: $\quad$ Surat Yakobus ini ditunjukkan kepada kedua belas suku yang ada di perantauan yaitu mereka yang sedang diombang ambingkan yang berkaitan dengan tingkat sosial ekonomi yang dihadapi oleh jemaat, yaitu persoalan diantara orang kaya dan orang miskin. Jadi surat ini ditulis diperkirakan sebalum tahun 62 Masehi. Dalam artikel ini menuliskan tentang implementasi ungkapan berbahagialah orang yang bertahan dalam pencobaan dalam Yakobus 1:12-15. Latar belakangnya adalah dimana Yakobus mengatakan bahwa orang yang berbahagia adalah orang yang bertahan dalam pencobaan. Dalam konteks ini berbicara mengenai bagaimana sikap orang dalam menghadapi pencobaan, dalam hal ini Yakobus menghimbau bagi kedua belas suku yang ada di perantauan supaya mereka bertahan dalam pencobaan, lebih mengasihi Allah, bertahan dalam iman mereka, dan selalu setia kepada Tuhan pada saat menghadapi pencobaan. Kebahagiaan yang sesungguhnya adalah orang diberkati oleh Tuhan, tetapi yang menjadi masalah adalah hanya sebatas mengerti tetapi ketika di perhadapkan suatu masalah, cobaan, dan kekurangan kebutuhan menjadi tidak bahagia, kurang bersyukur dengan apa yang dialami. Oleh karena itu artikel ini kembali mengingatkan orang percaya tentang prinsip bahagia yang sejati.

Kata Kunci: Implementasi, Kajian Biblikal, Berbahagialah, Bertahan, Pencobaan.

\section{LATAR BELAKANG MASALAH}

Pada umumnya orang memiliki konsep bahwa berbahagia apabila tidak mengalami berbagai pencobaan dalam hidupnya. Hidup yang dialami terasa mulus tanpa rintangan, memiliki harta yang banyak, dan kehidupan yang sukses. Namun konsep berbahagia berbeda dengan apa yang dikatakan dalam Kitab Yakobus. Dalam Kitab Yakobus 1:12 dikatakan: 
"berbahagialah orang yang bertahan dalam pencobaan, sebab apabila ia sudah tahan uji, ia akan menerima mahkota kehidupan yang dijanjikan Allah kepada barang siapa yang mengasihi Dia".

Pengertian kata berbahagia memiliki keragaman. ${ }^{1}$ Kata berbahagia memakai kata "Makarios" artinya "terberkati" karena dilimpahi berkat dan karunia Allah. ${ }^{2}$ Berbahagia adalah orang yang berani melakukan apa yang menjadi kehendak Allah dalam hidupnya, yang berusaha untuk mencari dan memperoleh sesuatu yaitu mahkota kehidupan yang dijanjikan bagi orang yang mengasihi Tuhan. Realitas menunjukkan ada banyak hal yang membuat manusia kehilangan kebahagiaan, karena diejek oleh temannya. ${ }^{3}$ Tidak berbahagia karena dia merasa Tuhan itu tidak bersama-sama dengan dia. ${ }^{4}$ Tidak bahagia karena penyakit yang diderita, ${ }^{5}$ tidak bahagia karena masalah ekonomi. ${ }^{6}$ Dalam konteks keKristenan ada banyak penderitaan yang dialami sehingga bisa menggocangkan bukan hanya psikis, tetapi juga fisik. Penderitaan itu adalah penganiayaan. ${ }^{7}$ Sejarah menunjukkan bagaimana penganiayaan menjadi salah satu cobaan yang terjadi kepada umat Kristen. ${ }^{8}$ Namun Alkitab justru menunjukkan prinsip yang kontras, yaitu bahagia dalam pencobaan. Bagaimanakah mengerti hal ini?.

Dari latar belakang tersebut maka perlu untuk dilakukan kajian Alkitab untuk mengerti maksud berbahagia. Apakah kebahagiaan identik dengan tanpa penderitaan, atau apakah

1 Beatific Vision, mengatakan pemandangan yang berbahagia menurut Skolastik adalah pengetahuan tentang Allah dan kesatuan dengan Allah yang adalah tujuan keberadaan manuasia dan yang dinikmati oleh orang-orang bahagia dalam sorga (Lih. : Henk Ten Napel, Kamus Teologi Inggris-Indonesia, (Jakarta:BPK Gunung Mulia, 2006), 52).Nouwen memberikan definisi dengan mengatakan berbahagia artinya terberkatilah orang yang suci hatinya, kata ini adalah hidup Yesus telah mengarah kepada orientasi dasarnya dan tidak terombang-ambingkan oleh bermacam-macam (Lih. : Hanri J. M. Nouwen, Mencari Makna Kekuasaan, (Yogyakarta: Kanisius, 2000), 27-28). Menurut Sanders, kata berbahagia adalah merupakan sebuah kata yang dimuliakan dalam pemakaiannya dalam Perjanjian Baru. Kata "berbahagia" telah diartikan patut dicemburui, diberi selamat, sangat bahagia, kaya secara rohani, beruntung, sangat berbahagia (Lih.: J. Oswald Sanders, Kedewasaan Rohani, (Bandung:Yayasan Kalam Hidup, 1994), 106).

${ }^{2}$ Stefaan Leks, Tafsiran Injil Matius, (Yogyakarta: Kanisius, 2003), 119

3 Paul Gunadi, Pengaruh Ejekan atau Olokan Terhadap Perkembangan Anak, Telaga, (2009), https://www.telaga.org/audio/pengaruh_ejekan_atau_olokan_terhadap_perkembangan_anak, diakses 5April 2017

4 ...., Ketika Tuhan Terasa Jauh, Persekutuan Remaja \& Pemuda GRII Bintaro-MRII BSD, (2014), https://reformedevangelicalyouth.wordpress.com/2014/03/24/ketika-tuhan-terasa-jauh/ diakses 05 April 2017

5 David Robson, Derita Penyakit Yang Disulut Oleh Pikiran, BBC News, (2016), https://www.bbc.com/indonesia/vert_fut/2016/05/160517_vert_fut_penyakit_pikiran diakses 05 April 2017

${ }^{6}$ Cahyadi Takariawan, Ketika Problematika Ekonomi Melanda Rumah Tangga, Kompasiana, (2015), https://www.kompasiana.com/pakcah/552c44676ea834b8348b4584/ketika-problematika-ekonomi-melandarumah-tangga diakses pada 05 April 2017.

${ }^{7}$ Sabar Subekti, Meningkat, Penganiayaan Terhadap Umat Kristen, Satu Harapan, (2013), http://www.satuharapan.com/read-detail/read/meningkat-penganiayaan-terhadap-umat-kristen dikases 05 April 2017.
8
Penindasan
Terhadap
Orang
Kristen,
Wikipedia,

https://id.wikipedia.org/wiki/Penindasan_terhadap_orang_Kristen, diakses 05 April 2017 
penderitaan bisa diniLAI sebagai sebuah kebahagiaan?. Dalam konteks surat Yakobus memberikan jawaban terhadap realitas kebahagiaan yang sejati, hal tersebut sangat berguna untuk dimplementasikan oleh orang percaya. Oleh karena itu melalui tulisan ini akan membahasa bagaimana implementasi kajian biblikal ungkapan berbahagialah orang yang bertahan dalam pencobaan dalam yakobus 1:12-15?.

\section{METODOLOGI PENELITIAN}

Metodologi yang digunakan untuk memperdalam pemahaman tentang berbahagialah orang yang bertahan dalam pencobaan berdasarkan Yakobus 1:12-15adalah metode penelitian deskriptif analisis dan literatur. Dalam penelitian ini penulis akan menggali makna berbahagialah orang yang bertahan dalam pencobaan berdasarkan Yakobus 1:12-15. Dalam metode ini akan membuat kajian eksegetis terhadap teks "makna ungkapan berbahagialah orang yang bertahan dalam pencobaan." berdasarkan Yakobus 1:12-15 dan memberikan komentar dari para pakar. Selanjutnya metode penelitian berkaitan dengan pengumpulan informasi yang relevan dengan masalah yang diteliti, mengenai teori-teori dari sejumlah buku-buku Literatur, konsep-konsep, serta temuan-temuan yang berkaitan dengan judul penelitian.

\section{LATAR BELAKANG SURAT YAKOBUS}

Surat Yakobus adalah surat yang pertama dari rangkaian surat yang disebut sebagai surat am (umum). ${ }^{9}$ Surat ini ditujukan kepada kedua belas suku diperantauan" (1:1) dua belas suku yang dimaksud disini bukan umat Israel, meLAInkan jemaat Kristen yang melihat dirinya sebagai ahli waris tradisi Yahudi. ${ }^{10}$ Bertolak dari penggunaan dalam PL, Istilah "dua belas suku" rupanya menunju pada umat Israel; sedangkan "perantauan" atau Diaspora dimksudkan untuk orang-orang Yahudi non Palestina yang tinggal diseluruh dunia RomawiYunani (Yoh 7:35). Karena dalam pemikiran Kristen gereja adalah Israel Baru maka surat ini kemungkinan dialamatkan untuk umat Kristen Yahudi yang berada di Palestina, Siria, atau di tempat LAIn. ${ }^{11}$

Dalam hal ini penulis Surat Yakobus tidak memperkenalkan diri ditulis "Yakobus" saja. pada hal nama Yakobus banyak di antara orang-orang Yahudi. Didalam Berjanjian Baru saja sudah kita temui lima oknum yakni:

\footnotetext{
${ }^{9}$ Donald Guthrie, Pengantar Perjanjian Baru Volume 3, (Surabaya : Momentum, 2009), 50

${ }^{10}$ LAI, Alkitab Edisi Studi, (Jakarta: Lembaga Alkitab Indonesia 2011), 2003 2010), 34

${ }^{11}$ Bambang Subandrijo, Menyingkap Pesan-Pesan Perjanjian Baru, (Bandung: Bina Media Informasi,
} 
1. Yakobus anak Zebedeus, (Mrk, 1:19; 3:17; 5:37; 10:35, 41; Kis. 1:13;12:2,)

2. Yakobus anak alfeus (Mrk. 3:18; Mat 10:3; Kis. 1:13)

3. Yakobus muda (Markus 15:40; 16:1)

4. Yakobus ayah Rasul Yudas (Luk 6:16; Kis 1:13)

5. Yakobus saudara Yesus (Mrk 6:3; Kis 12:17; 15:13; 21:18; Gal 1:19; 2:9,12; 1Kor $15: 7){ }^{12}$

Dalam buku Scheunemann mengatakan penulisan Surat Yakobus Yakobus 1:1 memberikan informasi penulis Surat Yakobus " Salam dari Yakobus, hamba Allah dan Tuhan Yesus Kristus penulis Yakobus memperkenalkan dirinya sebagai Yakobus yang dimaksud disini. Yakobus saudara Tuhan Yesus adalah, keungkinan terbesar, penulis kitab ini. Yakobus ayah Yudas tidak terlalu diperhitungkan seccara jelas sebagai penulis surat Yakobus. Hal yang sama berlaku bagi Yakobus anak Alfeus sekalipun derajat ketidakjelasannya lebih rendah. Yakobus anak Zebedeus memiliki kemungkinan yang lebih baik. Ia memiliki posisi penting diantara kedua belas rasul. Yakobus saudara Tuhan Yesus memiliki posisi penting dalam jemaat mula-mula.kemungkinan besar ia adalah penullis surat Yakobus. ${ }^{13}$

Tujuan penulisan surat ini adalah untuk memperingatkan bahaya dari orang fasik (34), untuk menyampaikan cara Allah menangani orang-orang yang memberontak (5-7) dan untuk menampilkan Yesus sebagai Mesias. ${ }^{14}$ Ladd, dalam bukunya mengatakan bahwa:

Yakobus tertarik dengan masalah pencobaan, yang mencerminkan pemikirannya tentang sifat manusia. Tampaknya ia terbiasa dengan orangorang Kristen yang tidak bertanggung jawab atas dosa-dosa yang mereka lakukan, dan pada dasarnya sama dengan menyalahkan Allah. Yakobus mengemukakan bahwa Allah tidak bisa dicobai atau mencobai seseorang untuk melakukan dosa. Setiap orang dicobai oleh keinginannya sendiri karena ia diseret dan di pikat olehnya $(1: 14){ }^{15}$

Seharusnya orang percaya, melakukan apa yang menjadi kehendak Allah dan tidak menuruti apa kata hati. Tetapi karena tidak melakukan perintah Tuhan, tidak sabar dalam menghadapi setiap masalah, hanya menuruti keinginannya sendiri, oleh karena sudah memikat atau melekat pada dirinya. Tetapi pencobaan tidak datang dari luar meLAInkan pencobaan atau ujian datang dari diri sendiri, karena hawa nafsu, adanya keinginan didalam batin, sehingga ketika datang pencobaan, yang datang dari luar dengan memberi umpan yang

\footnotetext{
${ }^{12}$ M.E. Duyverman, Pembimbing Kedalam Perjanjian Baru, (Jakarta: BPK Gunung Mulia, 2015), 175

${ }^{13}$ Rainer Scheunemann, Tafsiran Surat Yakobus Iman Dan Perbuatan (Yogyakarta: ANDI, 2013) 4-5

14 Daniel C. Arikhea, Pedoman Penafsiran Alkitab Surat Yudas Dan Surat Petrus Yang Kedua, (Jakarta: Lembaga Alkitab Indonesia, ), 4

${ }^{15}$ George Eldon Ladd, Teologi Perjanjian Baru: Jilid 2 (Bandung: Kalam Hidup, 2013), 400.
} 
tertarik, ia langsung menyambar karena dia dipikat oleh keinginannya. Latar belakang inilah yang mendorong Yakobus menuliskan surat ini.

\section{KAJIAN EKSEGETIS}

Selanjutnya akan dilakukan kajian eksegeris kata penting untuk mendapatkan makna ungkapan berbahagialah orang yang bertahan dalam pencobaan, berdasarkan Surat Yakobus $1: 12-15$.

\section{Berbahagialah}

Kata berbahagialah dalam bahasa Yunani $\mu \alpha \kappa \alpha \rho ı s$ (makarios) artinya yang berbahagia adalah yang penuh bahagia; yang diberkati. ${ }^{16}$ Dengan kasus adjective nominative masculine singular artinya kata sifat yang bentuk tunggal yang memakai kata ganti yang tidak menentu akan tetapi sedang berlangsung. Kata ini mengandung arti "berbahagialah, atau diberkatilah". ${ }^{17}$ Kata ini tertuju kepada orang yang mengasihi Tuhan yang mampu menahan diri dari berbagai pencobaan. Dalam Bahasa Inggris menggunakan kata blessed, yang artinya yang diberkati. Sutanto dalam bukunya: yang berbahagia adalah orang yang tahan uji dalam pencobaan atau godaan. Dalam ayat 12 orang yang menang dalam godaan. ${ }^{18}$ Penulis dapat menyimpulkan bahwa berbahagia adalah orang yang diberkati, yang berlimpah berkat karena dia bertahan dalam berbagai pencobaan atau ujian.

Versi Firman Allah Yang Hidup memakai kata "berbahagialah orang yang tidak berbuat salah pada saat ia menghadapi cobaan", dalam terjemahan lama memakai kata "berbahagialah orang yang sabar menanggung pencobaan", berdasarkan ungkapan "berbahagialah", ini merupakan bentuk ungkapan yang sangat umum (bANDIngkan Ayub 5:17; Mazmur 1:1; 32:2; Amsal 8:32,34). Dalam Perjanjaian Baru, ungkapan ini dipakai oleh Yesus pada Matius 5:3-11, dan Lukas 6:20-22. Kata berbahagialah digunakan untuk menggambarkan keadaan orang mengalami kebahagiaan yang benar atau sejati dalam batin. Berarti sikap bersemangat yang tegas yang tidak terpengaruh oleh keadaan yang bagaimanapun disekitarnya.

Ucapan berkat ini disampaikan kepada orang-orang yang bertahan melewati ujian iman. Berkat ini serupa dengan apa yang di tawarkan Yesus kepada orang-orang miskin dan orang-orang yang dirugikan pada Lukas 6:22-23, dalam konteks ini Allah sumber

\footnotetext{
${ }^{16}$ Hasan Sutanto, Perjanjian Baru Interlinear Yunani Indonesia, Jilid II (Jakarta: Lembaga Alkitab Indonesia, 2010), 498

17 Johannes E. Louw, Greek-English Lexicon of The New Testament, (New York: United Bible Societies, 1789), 121

${ }^{18}$ Sutanto, Surat Yakobus, (Malang: Literatur, 2006), 193
} 
kebahagiaan yang sejati, Dialah yang memberikan hal-hal yang baik. ${ }^{19}$ Artinya yang sangat berbahagia adalah Yesus Kristus, karena Yesus tidak mencobai manusia dan Dia juga tidak dapat dicobai. Berbahagia adalah sebuah berkat yang diucapkan kepada mereka yang bertahan dalam cobaan dan ujian, seperti yang dijelaskan dalam ayat 12 berbahagialah orang yang bertahan dalam pencobaan, bukan hanya orang menderita saja yang di berkati, meLAInkan juga orang yang bertahan, yang sabar, dan tekun melewati semua kesulitan dijalan kewajibannya. ${ }^{20}$ Jadi kata "berbahagialah" dapat disimpulkan adalah orang yang diberkati, orang yang hidup dalam Kristus, orang yang mengasihi Tuhan yang sabar dalam menghadapi ujian.

\section{Bertahan}

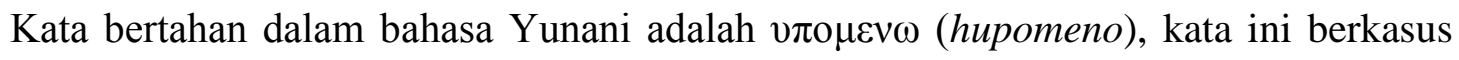
verb indicative present active 3rd person singular from artinya kata kerja yang bersifat normal bentuk tunggal yang tidak menentu artinya bertahan, atau bertekun. ${ }^{21}$ Kata bertekun merupakan kata perintah yang sedang dikerjakan dan tidak hanya sekali tetapi terus menerus. Defenisi Indonesia memakai kata berdiri teguh dan bersabar. Dalam bahasa Inggris memakai kata "to remain" artinya untuk tinggal, untuk berpegang teguh pada iman di dalam Kristus supaya mendapatkan kebahagiaan. ${ }^{22}$ Dengan demikian penulis memahami bahwa orang sabar dalam setiap persoalan masalah atau cobaan akan mendapatkan sukacita yang mulia. Pffeiffer dalam bukunya:

Pahala yang diperoleh mereka yang setia bertekun didalam penderitaan dinyatakan dalam waktu sekarang dan akan datang. Orang yang bertahan tersebut sekarang sudah berbahagia; tetapi dia juga akan menerima mahkota kehidupan yang dijanjikan Allah kepada barangsiapa yang mengasihi Dia. Bentuk genetif (kehidupan) merupakan keterangan dari mahkota. Mahkota tersebut yang terbuat dari kehidupan, sebuah anugerah yang diberikan kepada semua orang yang mengasihi Allah. ${ }^{23}$

Dalam Kamus Besar Bahasa Indonesia kata "bertekun", artinya berkeras hati dan sungguh-sungguh, belajar dalam menghadapi ujian, dapat di artikan sebagai ketekunan. Kata ketekunan yang dituliskan dalam ayat 3 dalam Terjemahan Baru memakai kata, "menjadi tabah", dapat diartikan ketekunan adalah kemampuan untuk menghadapi segala macam

\footnotetext{
${ }^{19}$ M.K. Sembiring, Pedoman Penafsiran Alkitab Surat Yakobus (Jakarta: LAI, 2009), 24

${ }^{20}$ Matthew Henry, Tafsiran Matthew Henry, Surat Ibrani, Yakobus, 1dan 2 Petrus, 1-3 Yohanes, Yudas, Kitab Wahyu (Momentum: Surabaya, 2016), 298

21 Barclay M. Newman, A Concise Greek-English Dictionary of The New Testament, (German: Deutsche Bibel Gesellschaft, 1993), 207

${ }^{22}$ Sabda 4, CD-ROM 2013), 1265

${ }^{23}$ Charles F. Pffeiffer, Tafsiran Alkitab Wyclife: Volume 3 Matius-Wahyu, (Malang: Gandum Mas,
} 
masalah, kesulitan dan penderitaan, dengan ketabahan dan kesetiaan yang teguh. Artinya bukan hanya sekedar bertahan dalam kesukaran dan cobaan. Karena itu beberapa terjemahan menerjemahkan tentang seseorang yang tetap setia ketika menghadapi pencobaan.

Versi LAIn New King James Version "Blessed is the man who endures temptation; for when he has been approved, he will receive the crownof life wichthe Lordhas promised to those who love Him". Artinya siapa yang memikul atau bertahan dalam godaan, ia akan menerima hidup yang mana Tuhan telah berjanji kepada mereka yang mencintai-Nya. Maksudnya orang percaya harus bersabar, pada saat ia menghadapi pencobaan sebab ia akan menerima mahakota yang telah dijanjikan Allah kepada mereka yang mengasihi Dia.

\section{Pencobaan}

Kata pecobaan dalam bahasa aslinya $\pi \varepsilon 1 \rho \alpha \sigma \mu \rho \varsigma$ (peirasmos) yang artinya pencobaan dan ujian, kata ini bekasus noun accusative masculine singular common from. Ini kata benda, yang bersifat menuduh secara umum dalam bentuk tunggal. ${ }^{24}$ Kata ini sedang dikerjakan. Jadi artinya pencobaan atau ujian, menunjuk kepada penganiayaan dan kesulitan yang datang dari dunia iblis. Namun pencobaan yang dimaksud Yakobus adalah sifat dan karakter seseorang dalam pencobaan yang berada dalam diri manusia. Kata pencobaan dalam (ay 12) mengandung arti menyeret orang ke dalam dosa. ${ }^{25}$ Tong mengatakan dalam bukunya: pencobaan atau ujian, ujian bertujuan untuk mengkonfirmasikan kita mendekat kedalam kesempurnaan yang sudah mahir. Ujian dimuLAI dengan segala kepahitan, kesengsaraan, penderitaan dan diakhiri dengan kemanisan, kebahagiaan, kemenangan, dan keindahan rohani. ${ }^{26}$ Maksudnya pencobaan tidak datang dari Allah, tetapi pencobaan datang dari diri manusia sendiri, oleh karena ia sudah di pikat oleh keinginannya. Scheunemann mengatakan dalam bukunya: orang berani menghadapi pencobaan melihat pencobaan sebagai alat yang akan menunjukkan ketahanan iman. ${ }^{27}$

Orang percaya harus menghadapi semuanya dengan sukacita (bANDIngkan dengan matius 5:11-12; Roma 5:3;1 Petrus 1:6) karena pengujian akan mengembangkan iman yang tabah yang mantap dan pengharapan yang dapat mencapai kedewasaan (bdg Roma 5:3-5). Iman orang percaya hanya dapat mencapai kedewasaan penuh apabila di perhadapkan dengan kesulitan dan tantangan (Yakobus 1:3). Yakobus menyebutkan aneka pencobaan ini "ujian terhadap imanmu". Pencobaan tidak terlepas dari diri orang percaya supaya Allah dapat

\footnotetext{
${ }^{24}$ Louw, Greek-English Lexicon Of Thenew Testament, 155.

${ }^{25}$ F. Harrison, Tafsiran Alkitab Wycliffe, Volume 3 Matius-Wahyu (Malang: Gandum Mas, 2003), 1265

${ }^{26}$ Stephen Tong, Ujian Pencobaan Dan Kemenangan, (Jakarta: Lembaga Reformed Injili Indonesia, 2003), 65

${ }^{27}$ Rainer Scheunemann. Tafsiran Surat Yakobus: Iman dan Perbuatan, (Yogyakarta: ANDI, 2013), 49
} 
menguji kesungguhan iman mereka. Alkitab tidak pernah mengajarkan bahwa kesuslitan didalam hidup ini selalu menandakan bahwa Allah tidak senang dengan orang itu. Redick dalam bukunya: setiap pencobaan adalah kesempatan bagi kita untuk membuktikan kasih kita kepada-Nya. ${ }^{28}$ Kesulitan tersebut dapat menjadi tanda bahwa Allah mengakui komitmen orang tersebut kepada Dia (Ayub 1:1-2:13). ${ }^{29}$ Wibowo dalam mengatakanbukunya:

Pencobaan adalah masalah pribadi; didalam ayat 14-15 "tetapi tiap-tiap orang dicobai menurut keinginannya sendiri, karena ia di seret dan dipikat olehnya." Dan apabila keinginan itu sudah matang, ia akan melahirkan dosa; dan apabila dosa itu sudah matang ia akan melahirkan maut. ${ }^{30}$

Penulis menyatakan setiap orang dicobai oleh karena keinginan, sehingga menimbulkan dosa, karena menuruti keinginan hati tidak mau menuruti kehendak Tuhan. Roni dalam bukunya:

kata pencobaan adalah sama dengan digoda atau diuji. Ketika Yesus dibawa oleh Roh Kudus ke padang Gurun untuk dicobai, arti harafiahnya Ia dibawa naik; ujian merupakan peningkatan supaya kita naik tingkat yang lebih tinggi daripada tingkat yang ada sekarang. Dalam pencobaan itu ada bimbingan dan pimpinan Tuhan didalam kehidupan kita; untuk kemajuan rohani dan iman, kita akan mengalami tantangan, godaan, dan pencobaan yang harus dilalui. Ujian duniawi beda dengan ujian sorgawi; dalam ujian duniawi kesalah dijadikan alasan untuk meninggalkan seseorang. Sedangkan ujian dalam pandangan Allah (ujian surgawi), kelemahan, kesalahan, dan kegagalan yang kita alami kita jadikan sebagai pembelajaran, karena tanpan Allah kita tidak ada artinya. ${ }^{31}$

Setiap manusia mengalami pencobaan, dan pencobaan tidak datang dari Allah, karena Allah tidak mencobai siapapun. Tetapi pencobaan datang dari diri orang tersebut, karena tiaptiap orang dicobai oleh keinginannya sendiri. Hallei kata pencobaan dalam bukunya:

Dalam ayat 2-3, yang menanggung pencobaan; pencobaan dalam ayat 2 berarti pengujian dari pada kesukaran-kesukaran; dalam ayat 12 yang dimaksud dengan kata itu ialah: pemikat hati kepada dosa. Melalui pencobaan-pencobaan yang pertama, yaitu kesukaran-kesukaran Tuhan menyempurnakan para waris kekekalan, 5:13-14. Iman yang diuji itu indah 1 Petrus 1:7. ${ }^{32}$

Dengan demikian orang percaya tidak akan takut menderita karena jikalau demikian itulah ujian iman dari Tuhan. Dalam Alkitab terjemahan Baru Bahasa Indonesia Sehari-hari

\footnotetext{
${ }^{28}$ Michael A. Redick, Mencapai Kedewasaan Yang Maksimal, (Yogyakarta: ANDI, 2010), 212

${ }^{29}$ Donald, C. Stamps, Alkitab Penuntun Edisi Bahasa Indonesia (Gandum Mas, 1993), 19

${ }^{30}$ Paulus Trimanto Wibowo, Jawaban Atas Pertanyaan-Pertanyaan Anda (Yogyakarta: ANDI, 2000), 72.

${ }^{31}$ K.A.M. Jusuf Roni, Berkat Yang Tercurah, (Yogyakarta: ANDI, 2001), 62

${ }^{32}$ Henry H. Hallei, Penuntun Kedalam Perjanjian Baru, Bagian Ketiga Ibrani- Wahyu, (Surabaya: Kembang Depun, 1973), 25.
} 
mengatakan, "saudara-saudara! Kalau kalian mengalami bermacam-macam cobaan, hendaklah kalian merasa beruntung”, jadi orang-orang yang disebutkan dalam nats ini berbahagia karena menderita dalam setiap masalah-masalah yang hadir dalam kehidupannya karena dengan begitu ia bisa bertumbuh di dalam Kristus. Dalam ayat 3, Yakobus menjelaskan bahwa ujian terhadap imanmu. Dalam Kamus Alkitab pencobaan adalah pengujian, Allah menguji Abraham melalui perintah untuk mengorbankan anaknya Ishak (Kejadian 22:1-9), arti yang LAIn yang lazim, yaitu bujukan "pada dosa yang tidak datang dari Allah" Yakobus 1:12-15. ${ }^{33}$

\section{Tahan Uji}

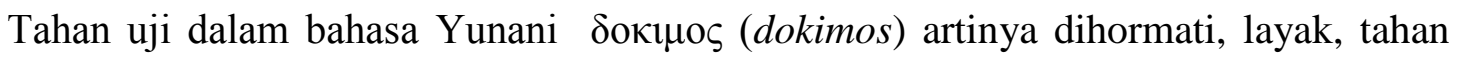
uji. Bentuk kata sifat yang normal nominative masculine singular no degree from. Kata sifat yang bentuk tunggal yang tidak menentu tetapi sedang di kerjakan artinya layak dihormati, karena tahan uji. ${ }^{34}$ Kata tahan uji dalam defenisi Indonesia bertahan dalam pencobaan berat. Maksudnya setiap orang percaya harus kuat imannya pada saat menghadapi setiap cobaan, dan mampu menahan diri supaya tidak mudah goyah iman pada saat mengalami berbagai masalah kepada Kristus.

Versi NKJV when he has been approved yang artinya ketika ia disetujui. artinya bertahan dalam pencobaan berat Yakobus 1:12; dihormati. Bertahan dalam pencobaan artinya layak, dapat dianggap sebagai orang yang dapat menerima mahkota kehidupan. Dalam tafsiran Matthew Henry mengatakan orang yang tahan uji atau bertahan menghadapi cobaan harus didasarkan dengan kasih kepada Allah dan Yesus Kristus Tuhan kita, sebab kalau tidak, maka ia tidak mempunyai kepentingan dalam janji ini; dijanjikan Allah kepada barangsiapa yang mengasihi Dia. Rasul Paulus berpendapat bahwa titik tertentu dalam kehidupan beriman. ${ }^{35}$ Versi LAIn Bahasa Indonesia Sehari-hari adalah "sebab sesudah ia berhasil bertahan dalam cobaan itu", maksud Yakobus dalam teks ini adalah orang yang sudah tahan uji, dialah yang akan menerima mahkota kehidupan. Dalam Terjemahan Baru kata mahkota atau upah yang dijanjikan Allah yaitu dapat diterjemahkan Allah akan membuat bahagia orang yang tahan uji menghadapi berbagai kesulitan (tetap percaya). Sebab, ketika dia terbukti berhasil, Allah akan memberikan hadiah kepadanya berupa kehidupan yang kekal. ${ }^{36}$

\footnotetext{
${ }^{33}$ W.R.F. Browning, Kamus Alkitab, (Jakarta: BPK Gunung Mulia, 2002), 323

${ }^{34}$ Barclay M. Newman, A Concise Greek-English Dictionary of The New Testament, (German: United Bible Societies, 1993), 51

${ }^{35}$ Newman, A Concise Greek-English Dictionary of The New Testament, 299

${ }^{36}$ Sembiring, Pedoman Penafsiran Alkitab Surat Yakobus, 26
} 
Penulis dapat menyimpulkan bahwa orang yang mampu menahan diri dalam pencobaan atau keinginan, yang datang dari diri sendiri, maka dialah yang memiliki hadiah yang dijanjikan Allah kepada barangsiapa yang mengasihi Dia, yaitu mahkota kehidupan. Basuki mengatakan :

Pencobaan adalah salah satu musuh orang Kristen. Jika kita tidak mengalahkannya, maka kita akan dikalahkannya. Orang yang memperoleh mahkota bukanlah orang yang kalah dan tidak tahan uji, meLAInkan orang yang kuat dan tahan uji. Karena itu wajib kita tahan uji walaupun kita menghadapi berbagai-bagai pencobaan. biarlah pencobaan-pencobaan itu semkin meneguhkan iman kita kepada Tuhan. Biarlah pencobaan itu semakin membuat kita bergantung kepada-Nya. Dengan demikian kita menjadi pemenang, dan layak menerima mahkota kehidupan. ${ }^{37}$

\title{
Mahkota Kehidupan
}

Mahkota kehidupan dalam bahasa Yunani adalah $\sigma \tau \varepsilon \varphi \alpha v o \varsigma$ (stephanos) jenis kata noun accusative masculine singular common from artinya bermahkota. ${ }^{38}$ Kata mahkota bersifat Kata benda yang bersifat menuduh umum bentuk tunggal, yang artinya mahkota yang yang di pakai sebagai perhiasan. Sutanto dalam bukunya:

\begin{abstract}
Mahkota ini bermakna, jika seorang bertahan (kalau dibANDIngkan dengan ketahanan, ayat 3), maka menjadi orang yang tahan uji. Dia akan menerima mahkota kehidupan (atau di terjemahkan: kehidupan kekal). Mahkota ini bermakna, karena dijanjikan Allah kepada orang-orang yang mengasihi-Nya. Kehidupan orang yang beriman tidak akan sia-sia. Perlu diperhatikan, dalam ayat 12 ini sudah muncul beberapa motif baru, misalnya: yang tahan uji, mahkota hidup kekal, yang dijanjikan, orang-orang yang mengasihi-Nya. Motif mahkota kehidupan kekal dapat diperhatikan, karena mahkota yang sesungguhnya berkaitan dengan kualitas kehidupan rohani yang bersangkutan. Mahkota ini tidak terbuat dari material, emas atau batu permata. Mahkota (atau hadiah, kehormatan) ini yang merupakan hidup kekal yang diberikan Allah. ${ }^{39}$
\end{abstract}

Dalam Kamus Alkitab mahkota pada umumnya dipakai sebagai perhiasan diatas kepala, atau permaisuri, (Kel 28:36; 2Taw 23:11; Ester 2:17). Mahkota dipakai selaku tanda penghormatan, kekuasaan dan hidup kekal, Amsal 12:4; 1Pet 5:4. Mahkota dalam Kamus Alkitab adalah sebagai hadiah atas kemenangannya (1Kor 9:25). Sebagai simbol kerajaan, Mahkota (suatu kata LAIn dalam bahasa Yunani) melambangkan kekuasaan (Wahyu. 9:7) dan kemualiaan (1 Petrus 5:4). Paulus menganggap pertobatannya sebagai mahkotanya (Filipi

37 Yusuf Eko Basuki, Kristen Pemenang: Meraih Kemenangan Iman Dengan Strategi Tuhan, (Yogyakarta: Garudhawaca, 2014), 161

38 Joseph Henry Thayer,. A Greek-English Lexicon Of The New Testament, (International Bible Translators (IBT), 1889), 185

${ }^{39}$ Sutanto, Surat Yakobus, 193 
4:1). ${ }^{40}$ DalamVersi Bahasa Indonesia Sehari-hari mengatakan, "ia akan menerima upahnya, yang berarti Allah telah menjanjikan upah kekal kepada mereka yang melayani-Nya dengan setia", maksudnya adalah orang yang menerima mahkota kehidupan adalah orang yang sungguh-sungguh mencari Dia.

Hidup kekal adalah dalam injil Yohanes adalah pada umumnya, sikap orang Yahudi tercermin dalam pengharapan Yahudi untuk menemukan hidup yang kekal dalam kitab suci (Yoh 5:39) adalah hal umum dalam ajaran-ajaran nabi bahwa mempelajari Taurat akan menuntun kepada kehidupan yang akan datang. ${ }^{41}$ Versi LAIn Bahasa Indonesia Sehari-hari, "berbahagialah orang yang tabah pada waktu ia mengalami cobaan. Sebab sesudah ia berhasil bertahan dalam cobaan itu, ia akan menerima upahnya, yaitu kehidupan yang telah dijanjikan Allah kepada orang-orang yang mengasihi Allah”, maksudnya, mahkota kehidupan menunjuk kepada orang-orang yang mengasihi Allah, yang tulus hatinya yang mampu menahan diri dari godaan atau ujian yang dialaminya, sehingga dapat menerima mahkota atau upah yang dijanjikan Allah yaitu mahkota kehidupan. Graham, menuliskan mereka yang berpegang pada hidup kekal akan menerima mahkota kehidupan. Sebagaimana yang dikatakan oleh Rasul Yakobus berbahagialah orang yang bertahan dalam pencobaan, sebab apabila ia sudah tahan uji, ia akan menerima mahkota kehidupan yang dijanjikan Allah kepada barangsiapa yang mengasihi Dia. (Yak 1:12). ${ }^{42}$

Maksudnya adalah orang yang menerima mahkota kehidupan tidak terkhusus kepada satu orang meLAInkan secara umum dikatakan barangsiapa yang mengasihi Dia. Barang siapa yang mengasihi Tuhan, yang di maksud Rasul Yakobus adalah orang yang mengasihi Dia dengan segenap hati dan dengan segenap jiwanya, untuk tetap bertahan dan teguh didalam Tuhan, yang bisa melewati berbagai pencobaan yang menimpa diri orang percaya tidak akan goyah, tidak akan terpengaruh oleh keinginannya oleh karena mengasihi Tuhan.

\section{Mengasihi Dia}

Kata mengasihi dalam bahasa Yunani yaitu $\alpha \gamma \alpha \pi \alpha \omega$ (agapao) kata ini berkasus participle present active dative masculine plural from artinya menagsihi Allah dengan tidak hentin-hentinya, menaruh kasih, mencintai, mengasihi, mengasihi-Nya. Dalam Versi LAIn, mengasihi adalah mencintai Tuhan, didalam kehidupannya; kata mengasihi dalam KBBI mengasihi Allah adalah perintah "Ul 11:1 "Haruslah engkau mengasihi Tuhan, Allahmu, dan

\footnotetext{
${ }^{40}$ Browning, Kamus Alkitab, 248

${ }^{41}$ George Eldon Ladd, Teologi Perjanjian Baru Jilid 1 (Kalam Hidup: Bandung, 2014), 338

${ }^{42}$ Billy Graham, Dimana Berada, Surga, Kekekalan Dan Hidup Kita Melampaui Yang Sekarang (Light Publishing, 2016), 277
} 
melakukan dengan setia kewajibanmu terhadap Dia dengan senantiasa berpegang pada segala ketetapan-Nya, peraturan-Nya dan perintah-Nya. Dalam Yosua 22:5 mengatakan "hanya, lakukanlah dengan sangat setia perintah dan hukum, yang diperintahkan kepadamu oleh Musa, hamba Tuhan itu, yakni mengasihi Tuhan, Allahmu, hidup menurut segala jalan yang ditunjukkan-Nya, tetap mengikuti perintah-Nya, berpaut pada-Nya dan berbakti kepada-Nya dengan segenap hatimu dan dengan segenap jiwamu." hukum yang terutama, hukum yang pertama (Mat 22:38).

Maksud Yakobus mengasihi Tuhan, adalah merupakan hukum yang terutama yaitu kasiihilah Tuhan, Allahmu, dengan segenap hatimu, dan dengan segenap jiwamu dan dengan segenap kekuatanmu (U1 6:5). Perintah untuk selalu setia kepada Tuhan, dan memberi untuk taat kepada perintah Tuhan dan melakukan firman Allah.

Yakobus membicarakan masalah yang datang dari dalam diri sendiri (Yak 1:12-15). Yakobus menjelaskan pendekatan psikologis mengenai kejatuhan manusia kedalam dosa. Yak 1:12 menekankan bahwa pencobaan memiliki positif bagi orang percaya, namun hal ini hanya berlaku bagi mereka yang menghadapi pencobaan dengan sikap yang benar. Oleh karena itu berbahagialah orang yang bertahan secara aktif dalam pencobaan. Orang yang berani menghadapi pencobaan sebagai alat uji yang akan menunjukkan ketahanan iman. Seseorang dapat dikatakan berbahagia dalam pencobaan, ini tidak menunjuk pada sisi duniawi, tetapi Allah. Tuhan telah menjanjikan mahkota kehidupan (wahyu 2:10), yaitu kehidupan kekal itu sendiri, kepada setiap orang yang telah menunjukkan bahwa ia sungguh mengasihi Allah dengan bertahan dalam pencobaan.

\section{Jahat}

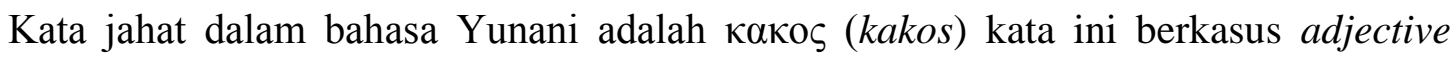
genitive neuter plural artinya kata sifat kata bersifat netral genetif jamak, artinya sifat dari seseorang yang buruk. ${ }^{43}$ Defenisi Bahasa Inggris memakai kata destructive, yang artinya bersifat merusak. Bahasa Indonesia Sehari-hari, "tetapi orang tergoda kalau ia ditarik dan dipikat oleh keinginannya sendiri yang jahat. Ini adalah kata sifat yang sedang dikerjakan, orang yang tergoda karena keinginannya, karena diseret dan dipikat oleh keinginannya sendiri, orang jatuh kedalam pencobaan oleh karena ia diseret dan terpikat oleh keinginannya sendiri, atau sebaliknya”. Dalam ayat 14 Yakobus mengatakan tiap-tiap orang didorong oleh keinginannya sendiri karena ia diseret dan pikat oleh yang jahat untuk melakukan kejahatan.

\section{Dicobai} Indices, 15

${ }^{43}$ Louw, Greek-English Lexicon Of The New Testament, Volume 1 Introduction \& Domains 2 
Kata apabila seorang dicobai dalam bahasa Yunani adalah $\pi \varepsilon \iota \rho \alpha \zeta \omega$ (peirazo) yang artinya ujilah, menggodai, pencobaan. Kata kerja indicative present passive 3rd person singular from. ${ }^{44}$ Kata dicobai yang kini hadir, diterjemahkan sebagai dicobai dan pencobaan dapat di artikan sebagai positif (baik) ataupun negatif (tidak baik) tergantung konteksnya. Dalam ayat ini yang dimaksud dengan pencobaan adalah sesuatu yang tidak baik yang bertujuan untuk menjatuhkan seseorang. Defenisi bahasa inggris memakai kata,to try or test one's faith, virtue, character, by enticement to sin. Artinya untuk mencoba atau menguji iman, kebaikan, karakter, dengan bujukan atau tawaran untuk berdosa. ${ }^{45}$

Kata dicobai tertuju kepada seseorang. Dalam sifat Allah, tidak ada yang bisa dipersalahkan: apabila seorang dicobai untuk berjalan di jalan kejahatan, atau melakukan apa saja yang jahat, janganlah ia berkata pencobaan ini datang dari Allah!" sebab Allah tidak dapat dicobai oleh yang jahat. Terjadi semua kejahatan moral karena ada kekacauan dalam makhluk yang bersalah atau kejahatan itu, akibat tidak ada hikmat. ${ }^{46}$ Maksudnya dicobai merupakan suatu ujian bagi orang percaya, untuk kekuatan imannya kepada Tuhan.

\section{Melahirkan Dosa}

Kata melahirkan dalam bahasa Yunani yaitu $\tau 1 \kappa \tau \omega$ (tikto) artinya melahirkan, menghasilkan, maksudnya adalah dalam ayat 15 apabila keinginan telah dibuahi, ia melahirkan dosa. Dosa dalam bahasa Yunani adalah $\alpha \mu \alpha \rho \tau \iota \alpha$ (hamartia) artinya dosa, berdosa. Jenis kata benda yang nominative umum bentuk tunggal, maksudnya adalah setiap perbuatan yang melawan hukum atau firman, Yohanes menuliskan setiap orang yang melanggar hukum Allah adalah dosa, sebab dosa ialah melanggar hukum Allah (1 Yoh 3:4). Setiap keinginan yang timbul dari manusia yang melawan dengan firman Tuhan, adalah dosa dan apabila keinginan sudah dibuahi, ia melahirkan dosa dan apabila dosa itu sudah matang ia melahirkan maut (Yak 1:15). Dalam Terjemahan Lama memakai kata memperanakkan dosa, Firman Allah Yang Hidup "kemudian pikiran jahat itu disusul oleh tindakan jahat yang mendatangkan hukuman mati dari Allah. Beal mengatakan, dosa adalah ketidakpatuhan kepada hukum, pelanggaran hukum" (1 Yoh 3:4) Allah. Dosa adalah tidak mau mempercayai Yesus Kristus. ${ }^{47}$ Maksudnya lahirnya dosa karena keinginan yang berasal dari dalam diri manusia, atau dalam batin manusia yang membiarkan keinginan itu matang sehingga karena

\footnotetext{
${ }^{44}$ Barbara Friberg, Analytical LexiconOf TheGreek New Testament, (Grand Rapids: Baker House, 2000), 154.

${ }^{45}$ Sabda 4, CD-ROM, Oktober 2017, Pukul 15:30 WIB.

${ }^{46}$ Henry, Surat Ibrani, Yakobus, 1Dan 2Petrus, 1-3 Yohanes, 300

${ }^{47}$ Billy Graham, Damai Dengan Allah (Jakarta: BPK Gunung Mulia, 1982), 51
} 
akibat dosa dan keinginan yang datang dari dalam hati orang percaya malahirkan maut atau kematian sebagai hukuman dari Allah. Dengan pandangan di atas adanya dosa karena tidak patut kepada Tuhan, akibat melanggar hukum atau perintah Allah dan tidak mau melakukan firman Allah. Berdasarkan pandangan tersebut, Hadiwijono mengatakan dengan lahirnya dosa oleh karena keinginan manusia maka, akibat dosa adalah terkena murka Allah. Didalam Alkitab murka Tuhan Allah sering diberitakan sebagai hukuman baru akan terjadi kelak pada akhir zaman. ${ }^{48}$

\section{Melahirkan Maut}

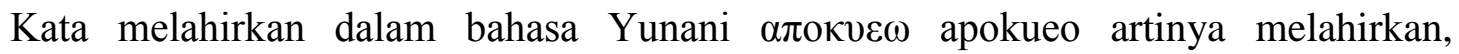
menjadikan. Kata melahirkan berkasus kata benda accusative masculine singular common from. Artinya kata benda yang menuju kepada objek yang menyatakan sedang berlangsung. Melahirkan dalam defenisi Bahasa Inggris memakai kata "from the womb" artinya dari kandungan (itu), kata melahirkan dapat diartikan sebagai hasil. Scheunemann mengatakan:

hasil dari dosa adalah kematian. Hal yang dimaksud disini adalah kematian kekal secara rohani (Roma 6:23), yaitu keterpisahan kekal dari Allah. Gambaran Yakobus sejalan dengan peristiwa kejadian 3: (1) godaan dari luar (ular); (2) godaan (pencobaan); menyeret dan memikat keinginan; (3) persetujuan (pembuahan keinginan dan kehendak); (4)dosa terjadi, yaitu keterpisahan dari Tuhan; dan (5) kematian secara jasmani dan rohani sebagai hasil dari dosa. Yakobus menggambarkan situasi yang dihadapi setiap orang (baik Kristen ataupun bukan) hari demi hari (mau atau tidak mau). Manusia tanpa Kristus dapat meraih berbagai kemenangan atas pencobaan, tetapi kemenangan mutlak tidak dapat ia peroleh. Pengikut Kristus dapat menang atas pencobaan karena Tuhan telah menang. Kemenangan ini adalah mutlak. ${ }^{49}$

Maksudnya adalah keinginan seseorang dapat melahirkan dosa, dosa diperkuat oleh perbuatan-perbuatan yang sering dilakukan yang menjadi kebiasaan karena bertahan tidak melakukan hukum atau perintah Allah, keinginannya sehingga dengan keinginan yang sudah memikat dan menjadi kebiasaan membuahkan atau melahirkan maut atau kematian. Hanry mengatakan upah dosa adalah kematian kekal.

\section{IMPLEMENTASI KAJIAN BIBLIKAL UNGKAPAN BERBAHAGIALAH ORANG YANG BERTAHAN DALAM PENCOBAAN DALAM YAKOBUS 1:12-15}

Dari hasil kajian eksegetis Yakobus 1:12-15 ada beberapa prinsip-prinsip teologis penting yang dapat diimplementasikan bagi kehidupan orang percaya yang sedang mengalami penderitaan. Dan bergumul tentang kebahagiaan yang sejati.

\footnotetext{
${ }^{48}$ Harun Hadiwijono, Iman Kristen, (Jakarta: BPK Gunung Mulia, 1990), 241

${ }^{49}$ Scheuneman, Tafsiran Surat Yakobus Iman Dan Perbuatan (Yogyakarta: ANDI, 2013), 55
} 


\section{Tidak Menuduh Allah Melakukan Yang Jahat}

Pencobaan adalah mengandung arti menyeret orang kedalam dosa atau menuju pada kesukaran dan penderitaan. Pencobaan bukan dari Allah tetapi pencobaan datang dari diri seseorang karena keinginan, (ayat 13-15). Berbicara tentang keinginan tidak selalu merupakan dosa. Kalau kita mempunyai keinginan untuk menaati Tuhan, melayani Tuhan, ini merupakan hal yang baik. Tetapi banyak keinginan yang bersifat dosa, seperti ingin barang orang LAIn (iri hati), ingin berzinah, ingin membalas kejahatan dengan kejahatan. Keinginan yang berdosa inilah yang dimaksudkan pencobaan dalam ayat 13 keinginan itu sendiri, sekalipun belum di turuti tetapi sudah merupakan dosa. ${ }^{50}$

Pencobaan tidak datang dari Allah meLAInkan dalam diri seseorang karena ia sudah diseret oleh keinginannya sendiri. Tetapi Tuhan menghendaki supaya setiap orang percaya dapat bertahan dalam pencobaan, dan mampu meniLAI pencobaan merupakan ujian untuk dapat mendewasakan rohani. Robert R. dalam bukunya : "pencobaan adalah alat yang disediakan Allah untuk memproses kedewasaan mencapai kesempurnaan". 51 Penulis menyimpulkan bahwa pencobaan tidak berasal dari Allah, karena Allah tidak dapat dicobai oleh yang jahat dan Allah tidak mencobai siapapun.

\section{Introspkesi Diri}

Keinginan seseorang dapat menimbulkan hati seseorang menjauh dari Tuhan. Pada dasarnya orang Kristen sudah tahu tentang Yudas Iskariot yang menjual Tuhan Yesus hanya dengan seharga 30 keping perak. Namun, salah sekali jika orang Kristen mengatakan bahwa semua niat jahat berasal dari iblis. Sama halnya dengan pencobaan yang datang dari diri sendiri dan dari iblis. Tidak semua niat jahat berasal dari iblis, tetapi bisa saja dari manusia itu sendiri dan iblis menyediakan jalan dan untuk menggenapi niat jahat dengan tujuan untuk melawan dan menyakiti Bapa. ${ }^{52}$

Berdasarkan ayat 14-15 tentang kata "tiap-tiap orang dicobai menurut keinginanya sendiri”, maka penulis menyimpulkan bahwa setiap keinginan manusia, tidak semua berasal dari iblis tetapi berasal dalam diri seseorang. Ini disebabkan karena keinginan dan ketika keinginan jahat itu muncul didalam pikiran seseorang tersebut dan tidak berhenti, karena keinginannya sendiri yang menyeret dan memikat dirinya untuk berbuat dosa. Kalau keinginan jahat dituruti akan melahirkan dosa dan apabila dosa sudah matang akan melahirkan maut (Roma 6:23). Stams mengatakan:

\footnotetext{
${ }^{50}$ Budi Asali, Eksposisi Surat Yakobus, diakses 2017

${ }^{51}$ Robert R. Tabloit Reformata, (1 Dolog Margu :Yayasan Pelayanan Media Antiokhia: 2009), 11

52 Nugroho Sapto prabowo, Terang Hidup Renungan Dewasa, 'Majalah' (2017). Grasindo, 142
} 
Dicobai oleh keinginan jahatnya sendiri. Pencobaan pada hakikatnya bersumber pada keinginan atau kecenderungan didalam hati kita sendiri (bd Matius 15:19) karena dari hati timbul segala pikiran jahat, pembunuhan, perzinahan, percabulan, pencurian, sumpah palsu, dan hujat. Apabila keinginan jahat ini tidak dilawan dan disingkirkan oleh Roh Kudus, maka itu menuntun kepada dosa dan kemudian kepada kematian rohani (ay 15; Roma $6: 23 ; 7: 5,10,13)$ " Roma 6:23 sebab upah dosa ialah maut; tetapi karunia Allah ialah hdup yan kekal dalam Kristus Yesus, Tuhan kita".53

\section{Tahan Uji Dalam Pencobaan}

Pencobaan yang dimaksud adalah sifat dan karakter seseorang yang berada dalam batin manusia, yang bertujuan untuk menjatuhkan seseorang dalam dosa dalam arti menjauh dari Tuhan. Dalam ayat 12 mengandung arti menyeret orang kedalam dosa. Hubungannya dengan tahan uji adalah sebagai orang percaya harus meniLAI setiap pencobaan yang dialami, bertujuan untuk lebih mendekat kepada kesempurnaan. Ujian dimuLAI dengan segala kepahitan, kesengsaraan penderitaan, dan diakhiri dengan kebahagiaan, kemenangan dan keindahan rohani.

Tahan uji adalah sifat yang dimiliki oleh orang percaya, yang layak dihormati karena tahan uji. Tahan uji yang di maksud adalah sesudah mengalami pencobaan dan masih tetap bertahan ataupun menang dalam ujian. Tahan uji menimbulkan pengaharapan. ${ }^{54}$ Orang yang tahan uji adalah orang memiliki hubungan yang dekat kepada Tuhan. Yulianto dalam bukunya mengatakan bahwa untuk menjadi seorang yang tahan uji tentunya orang percaya harus memiliki hubungan yang akrab dengan Tuhan setiap hari dengan terus hidup didalam Firman Tuhan. ${ }^{55}$ Werelden Fan dalam bukunya mengatakan tidak LAIn dari sebuah pilihan adalah sebuah proses yang ditawarkan untuk menentukan tahan uji atau tidak tahan uji "kebenaran" yang dihasilkan oleh manusia. ${ }^{56}$

\section{Berbahagia Dalam Pencobaan}

Yakobus menjadikan sebuah pencobaan sebagai kebahagiaan karena melalui pencobaan, ia tahan uji artinya bertahan tidak akan goyah imannya pada saat menghadapi pencobaan atau penderitaan. Melalui pencobaan ia memiliki pengharapan yaitu mahkota. Pfeiffer mengatakan:

Orang yang bertahan tersebut sekarang sudah berbahagia: tetapi dia juga akan menerima mahkota kehidupan yang dijanjikan Allah kepada barang siapa yang mengasihi Dia. Bentuk genetif (kehidupan) merupakan keterangan dari

\footnotetext{
${ }^{53}$ Stamps, Alkitab Penunutun Hidup Berkelimpahan, 2085

${ }^{54}$ Newman, Pedoman Penafsiran Alkitab: Surat Roma, 103

${ }^{55}$ Tomi Yulianto, Kitab Roma:Aplikasi Kehhidupan Remaja Dan Dewasa, (AA. Ricky, 2017)

${ }^{56}$ De. Werelden Fan, Teologi Dan Praksis Komunitas Post Modern, (Yogyakarta: Kanisius, 1994), 15
} 
mahkota. Mahkota yang terbuat dari kehidupan, sebuah anugerah yang diberikan kepada semua orang yang mengasihi Allah. ${ }^{57}$

Penulis menyimpulkan bahwa setiap pencobaan mendatangkan kebahagiaan apabila seseorang memiliki hubungan yang erat kepada Allah. Kemudian orang berbahagia dalam pengharapan. Pengharapan yang dimaksud adalah pengharapan tentang kehidupan kekal yang dijanjikan Allah kepada barangsiapa yang mengasihi Dia.

\section{PENUTUP}

Dari penjelasan Yakobus dan pandangan para tokoh tentang makna ungkapan berbahagialah orang yang bertahan dalam pencobaan, menurut Yakobus 1:12-15 dapat disimpulkan bahwa setiap orang percaya harus mengetahui makna ungkapan berbahagialah orang yang bertahan dalam pencobaan yaitu : Seorang yang percaya kepada Kristus harus mampu menghadapi cobaan atau ujian.

Berdasarkan pemaparan tentang makna ungkapan berbahagialah orang yang bertahan dalam pencobaan, menunjukkan bahwa orang percaya harus mampu menahan diri dari berbagai pencobaan atau godaan yang datang dari luar atau dari dalam diri, oleh karena keinginan sendiri. Ini sesuai dengan apa yang dikatakan dalam Kitab Yakobus, "berbahagialah orang yang bertahan dalam pencobaan, sebab apabila ia sudah tahan uji ia akan mendapatkan mahkota yang dijanjikan Allah kepada mereka yang mengasihi Dia" (Yakobus 1:12).

Pencobaan bukan dari Allah, karena Allah tidak dapat dicobai oleh siapapun dan Allah tidak mencobai siapapun, karena Allah adalah sumber dari segala sesuatu yang dapat mengubahkan pencobaan sebagai kebahagiaan. Pencobaan berasal dari keinginan diri sendiri, seseorang jatuh dalam dosa karena keinginan jahat dan disertai dengan perilaku, karena menuruti keinginan tidak menuruti kehendak Tuhan sehingga akibatnya adalah kematian. Melalui pencobaan menimbulkan tahan uji dan pengharapan didalam Tuhan. Melalui pencobaan mendatangkan kebahagiaan bagi setiap orang yang mengasihi Tuhan. Dengan demikian orang yang mampu melewati pencobaan dan mampu bertahan dalam ujian akan berbahagia karena mempunyai pengharapan mahkota kehidupan yang dijanjikan Allah kepada barangsiapa yang mengasihi Dia.

\footnotetext{
${ }^{57}$ Charles F. Pfeiffer, Tafsiran Alkitab Wicliffe Volume 3 Pejanjian Baru..., 972
} 


\section{DAFTAR PUSTAKA}

... (...). Sabda 4, CD-ROM.

.... (2011). LAI, Alkitab Edisi Studi, Jakarta: Lembaga Alkitab Indonesia.

....(...). Penindasan Terhadap Orang Kristen, Wikipedia, https://id.wikipedia.org/wiki/Penindasan_terhadap_orang_Kristen.

....(2014). Ketika Tuhan Terasa Jauh, Persekutuan Remaja \& Pemuda GRII Bintaro-MRII BSD, https://reformedevangelicalyouth.wordpress.com/2014/03/24/ketika-tuhanterasa-jauh/.

Arikhea, Daniel C. (....). Pedoman Penafsiran Alkitab Surat Yudas Dan Surat Petrus Yang Kedua, Jakarta: Lembaga Alkitab Indonesia.

Asali, Budi. (....). Eksposisi Surat Yakobus.

Basuki, Yusuf Eko. (2014). Kristen Pemenang:Meraih Kemenangan Iman Dengan Strategi Tuhan, Yogyakarta: Garudhawaca.

Browning, W.R.F. (2002). Kamus Alkitab, Jakarta: BPK Gunung Mulia.

Duyverman, M.E. Pembimbing Kedalam Perjanjian Baru, Jakarta: BPK Gunung Mulia.

Fan, De. Werelden. (1994). Teologi Dan Praksis Komunitas Post Modern, Yogyakarta: Kanisius.

Friberg, Barbara. (2000). Analytical Lexicon of The Greek New Testament, Grand Rapids: Baker House.

Graham, Billy. (2016). Dimana Berada, Surga, Kekekalan Dan Hidup kita Melampaui Yang Sekarang, Ligh Publishing.

Gunadi, Paul. (2009). Pengaruh Ejekan atau Olokan Terhadap Perkembangan Anak, Telaga, https://www.telaga.org/audio/pengaruh_ejekan_atau_olokan_terhadap_perkembangan _anak.

Gutrie, Donald. (2009). Pengantar Perjanjian Baru Volume 3, Surabaya : Momentum.

Hadiwijono, Harun. (1990). Iman Kristen, Jakarta: BPK Gunung Mulia.

Hallei, Henry H. (1979). Penuntun Kedalam Perjanjian Baru, Bagian Ketiga Ibrani- Wahyu, Surabaya: Kembang Depun.

Harrison, F. (2003). Tafsiran Alkitab Wiclyffe, Volume 3 Matius-Wahyu, Malang: Gandum Mas.

Henry, Matthew. (2016). Tafsiran Matthew Henry, Surat Ibrani, Yakobus, 1dan 2 Petrus, 1-3 Yohanes, Yudas, Kitab Wahyu. Momentum: Surabaya.

Ladd, George Eldon. (2013). Teologi Perjanjian Baru: Jilid 1, Kalam Hidup: Bandung. (2014). Teologi Perjanjian Baru Jilid 2, Kalam Hidup: Bandung. 
Leks, Stefaan. (2003). Tafsiran Injil Matius, Yogyakarta: Kanisius.

Louw, Johannes E. (1789). Greek-English Lexicon of The New Testament, New York: United Bible Societies.

Louw, Johannes. (1888). Greek-English Lexicon of The New Testament.

Napel, Henk Ten. (2006). Kamus Teologi Inggris-Indonesia, Jakarta: BPK Gunung Mulia.

Newman, Barclay M. (1993). A Concise Greek-English Dictionary of The New Testament, German: Deutsche Bibel Gesellschaft.

Nouwen, Hanri J. M. (2000). Mencari Makna Kekuasaan, Yogyakarta: Kanisius.

Pffeifer, Charles F. (2013). Tafsiran Alkitab Wyclife: Volume 3 Matius-Wahyu, Malang: Gandum Mas.

Prabowo, Nugroho Sapto. (2017). Terang Hidup Renungan Dewasa, Grasindo.

R., Robert. (2009). Tabloit Reformata, 1 Dolog Margu :Yayasan Pelayanan Media Antiokhia.

Redick, Michael A. (2010). Mencapai Kedewasaan Yang Maksimal, Yogyakarta: ANDI

Robson, David. (2016). Derita Penyakit Yang Disulut Oleh Pikiran, BBC News, https://www.bbc.com/indonesia/vert_fut/2016/05/160517_vert_fut_penyakit_pikiran.

Roni, K.A.M. Jusuf. (2001). Berkat Yang Tercurah, Yayasan ANDI: Yogaykarta.

Sanders, J. Oswald. (1994). Kedewasaan Rohani, Bandung:Yayasan Kalam Hidup.

Scheunemann, Rainer. (2013). Tafsiran Surat Yakobus Iman Dan Perbuatan, Yogyakarta: ANDI.

Sembiring, M.K. (2009). Pedoman Penafsiran Alkitab Surat Yakobus, Jakarta: LAI.

Stamps, Donald C. (1994). Alkitab Penunutun Hidup Berkelimpahan, Malang: Gandum Mas.

Subandrijo, Bambang. (2010). Menyingkap Pesan-Pesan Perjanjian Baru, Bandung: Bina Media Informasi.

Subekti, Sabar. (2013). Meningkat, Penganiayaan Terhadap Umat Kristen, Satu Harapan, http://www.satuharapan.com/read-detail/read/meningkat-penganiayaan-terhadapumat-kristen.

Sutanto, Hasan. (2006) Surat Yakobus, Malang: Literatur SAAT.

(2010). Perjanjian Baru Interlinear Yunani Indonesia, Jilid II. Jakarta: Lembaga Alkitab Indonesia.

Takaeiawan, Cahyadi. (2015). Ketika Problematika Ekonomi Melanda Rumah Tangga, Kompasiana,https://www.kompasiana.com/pakcah/552c44676ea834b8348b4584/keti ka-problematika-ekonomi-melanda-rumah-tangga. 
Thayer, Joseph Henry. (1889). A Greek-English Lexicon Of The New Testament, International Bible Translators (IBT).

Tong, Stephen. (2003). Ujian Pencobaan Dan Kemenangan, Jakarta: Lembaga Reformed Injili Indonesia.

Wibowo, Paulus Trimanto. (2000). Jawaban Atas Pertanyaan-Pertanyaan Anda, Yayasan Yogyakarta: ANDI.

Yulianto, Tomi. (2017). Kitab Roma: Aplikasi Kehhidupan Remaja Dan Dewasa, AA. Ricky. 